\title{
Solid Oxide Fuel Cell Development at Topsoe Fuel Cell A/S and Risø National Laboratory
}

Christiansen, Niels; Hansen, J B.; Larsen, H H.; Linderoth, Søren; Larsen, Peter Halvor; Hendriksen, Peter Vang; Hagen, Anke

\author{
Published in: \\ E C S Transactions \\ Link to article, DOI: \\ $10.1149 / 1.2729070$ \\ Publication date: \\ 2007
}

Document Version

Publisher's PDF, also known as Version of record

Link back to DTU Orbit

Citation (APA):

Christiansen, N., Hansen, J. B., Larsen, H. H., Linderoth, S., Larsen, P. H., Hendriksen, P. V., \& Hagen, A. (2007). Solid Oxide Fuel Cell Development at Topsoe Fuel Cell A/S and Risø National Laboratory. E C S Transactions, 7(1), 31-38. https://doi.org/10.1149/1.2729070

\section{General rights}

Copyright and moral rights for the publications made accessible in the public portal are retained by the authors and/or other copyright owners and it is a condition of accessing publications that users recognise and abide by the legal requirements associated with these rights.

- Users may download and print one copy of any publication from the public portal for the purpose of private study or research.

- You may not further distribute the material or use it for any profit-making activity or commercial gain

- You may freely distribute the URL identifying the publication in the public portal 


\title{
Solid Oxide Fuel Cell Development at Topsoe Fuel Cell A/S and Riso National Laboratory
}

\author{
N. Christiansen ${ }^{\mathrm{a}}$, J. B. Hansen ${ }^{\mathrm{a}}$, H. Holm-Larsen ${ }^{\mathrm{a}}$, S. Linderoth ${ }^{\mathrm{b}}$, P. H. Larsen ${ }^{\mathrm{b}}$, \\ P. V. Hendriksen ${ }^{\mathrm{b}}$ and A. Hagen ${ }^{\mathrm{b}}$ \\ ${ }^{a}$ Topsoe Fuel Cell A/S, Nymøllevej 55, DK-2800 Lyngby, Denmark \\ ${ }^{\mathrm{b}}$ Risø National Laboratory, DK-4000 Roskilde, Denmark
}

The consortium of Topsoe Fuel Cell A/S and Risø National Laboratory has up-scaled its production capacity of anodesupported cells to about 1100 per week. Stacks are based on a compact thin plate multilayer design with metallic interconnects and $12 \times 12 \mathrm{~cm}^{2}$ or $18 \times 18 \mathrm{~cm}^{2}$ foot print. Larger $\left(500 \mathrm{~cm}^{2}\right)$ cells are currently under evaluation. Stacks have been tested successfully for more than $13000 \mathrm{~h}$. Several 50 or 75 cell stacks in the $1+\mathrm{kW}$ power range have been tested successfully at a fuel utilisation of up to $92 \%$. Multi stack modules consisting of four 75 cell stacks have been tested for more than $4000 \mathrm{~h}$ with pre-reformed natural gas and modules consisting of twelve stacks are under development. The degradation rate has been reduced to below $0.5 \%$ per $1000 \mathrm{~h}$, especially by improvement of metal alloy interconnects and coatings. Our SOFC program comprises development of next generation cells with metallic support for operation at lower temperature. In this case porous ferritic steel is used as a cheap, ductile, robust cell support and the electrolyte is based on scandiastabilized zirconia with improved durability. Furthermore, the metal supported cells offer a significantly improved tolerance towards redox cycling. In collaboration with Wärtsilä, a 24-stack prototype based on natural gas is being tested. For methanol based systems the methanol is methanated upstream the anode using a newly developed proprietary Haldor Topsoe catalyst. The range of fuels have further been extended to include ethanol and coal syngas by development of a new coke resistant catalyst suitable for future SOFC technology.

\section{Background}

Topsoe Fuel Cell A/S (TOFC) and Risø National Laboratory (Risø) are jointly carrying out a development programme focusing on low cost manufacturing of planar anode-supported cells and stacks employing metallic interconnects. The consortium of TOFC and Risø has up-scaled its production capacity of anode-supported cells to about 1100 cells per week. The consortium has an extended program to develop the SOFC technology all the way to a marketable product. The road to a successful SOFC technology is first and foremost governed by the ability to produce reliable and costeffective cells and stacks. 


\section{Cell Development and Production}

The production facility at Risø jointly operated by Risø and TOFC has now celebrated its 5 years anniversary. The number of anode supported cells (referred to as second generation cells, 2G) produced for development and demonstration of stack technology at TOFC and partners has increased rapidly as shown in . The number of cells produced in 2006 exceeded 12.000. The composition of the $2 \mathrm{G}$ cell has been frozen since 2004 and focus has been on improvement of the manufacturing process aiming at improved performance as well as reduction of rejection rate. The cell size has been scaled up such that cells in the size of $18 \times 18 \mathrm{~cm}^{2}$ are routinely produced. The largest cell manufactured so far is $1250 \mathrm{~cm}^{2}(1)$.

The $2 \mathrm{G}$ cell is based on the classical materials: LSM-YSZ cathode, YSZ electrolyte and Ni-YSZ anode and anode support. This cell type is very well characterized with respect to performance and durability (2). The average ASR at $850^{\circ} \mathrm{C}$ is $0.18+/-0.03$ $\Omega \mathrm{cm}^{2}$ with a degradation rate below $0.6 \% / 1000 \mathrm{~h}$ for current loads up to $1 \mathrm{~A} / \mathrm{cm}^{2}$. However, to achieve the same high performance at lower temperatures, and to obtain an improved mechanical stability, new cell generations are also being developed. Two lines are currently being pursued: 1) improvement of cells based on Ni-YSZ anode supports and 2) development of metal supported cells, 3G.

Based on the $2 \mathrm{G}$ half cells, a cell for operation around $700{ }^{\circ} \mathrm{C}$ is being developed with an LSCF cathode and a ceria barrier layer between the cathode and the YSZ electrolyte. New types of supports based on Ni-YSZ are also under development aiming at higher mechanical strength and improved redox stability $(1,3)$. Examples of the achieved mechanical strength, as measured in a ball-on-ring biaxial test (sample diameter $\sim 2 \mathrm{~cm}$ ) are given in Figure 2. The average biaxial strength of the $2 \mathrm{G}$ standard cells is $315 \mathrm{MPa}$ with a "minimum strength" of $275 \mathrm{MPa}$, and as is evident from Figure 2, the mechanical strength can be improved considerably up to a "minimum strength" of $350 \mathrm{MPa}$ by modification of the manufacturing parameters (4).

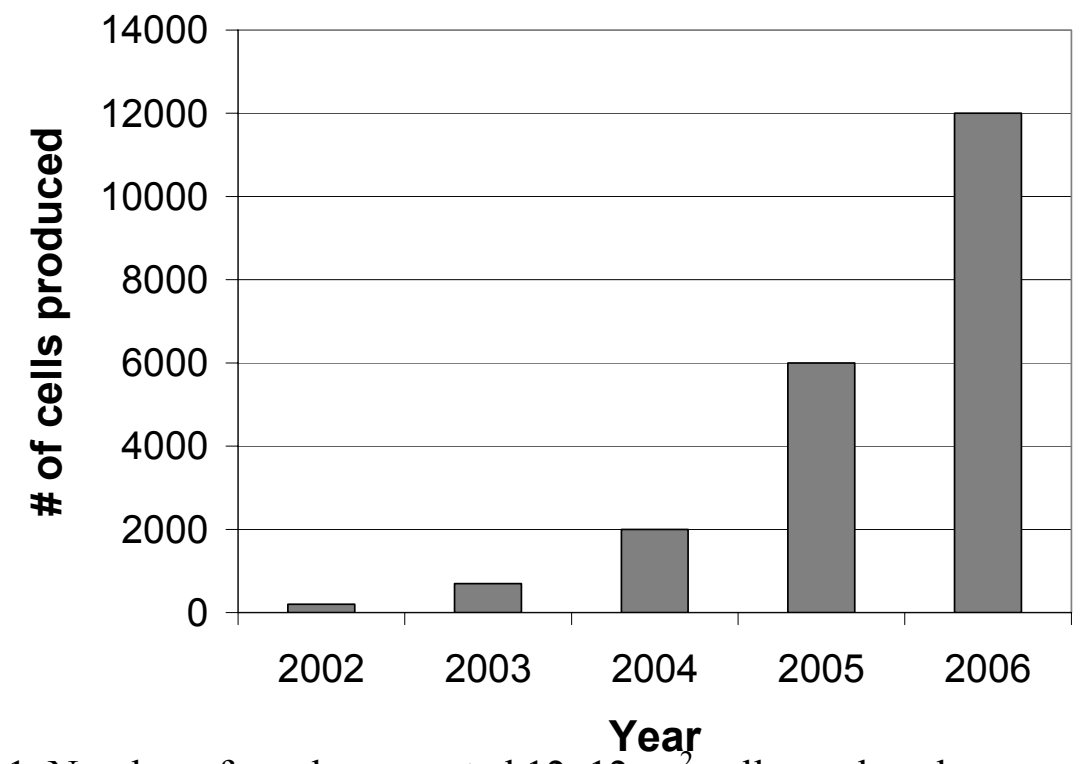

Figure 1. Number of anode supported $12 \times 12 \mathrm{~cm}^{2}$ cells produced per year from 2002 to 2006. 


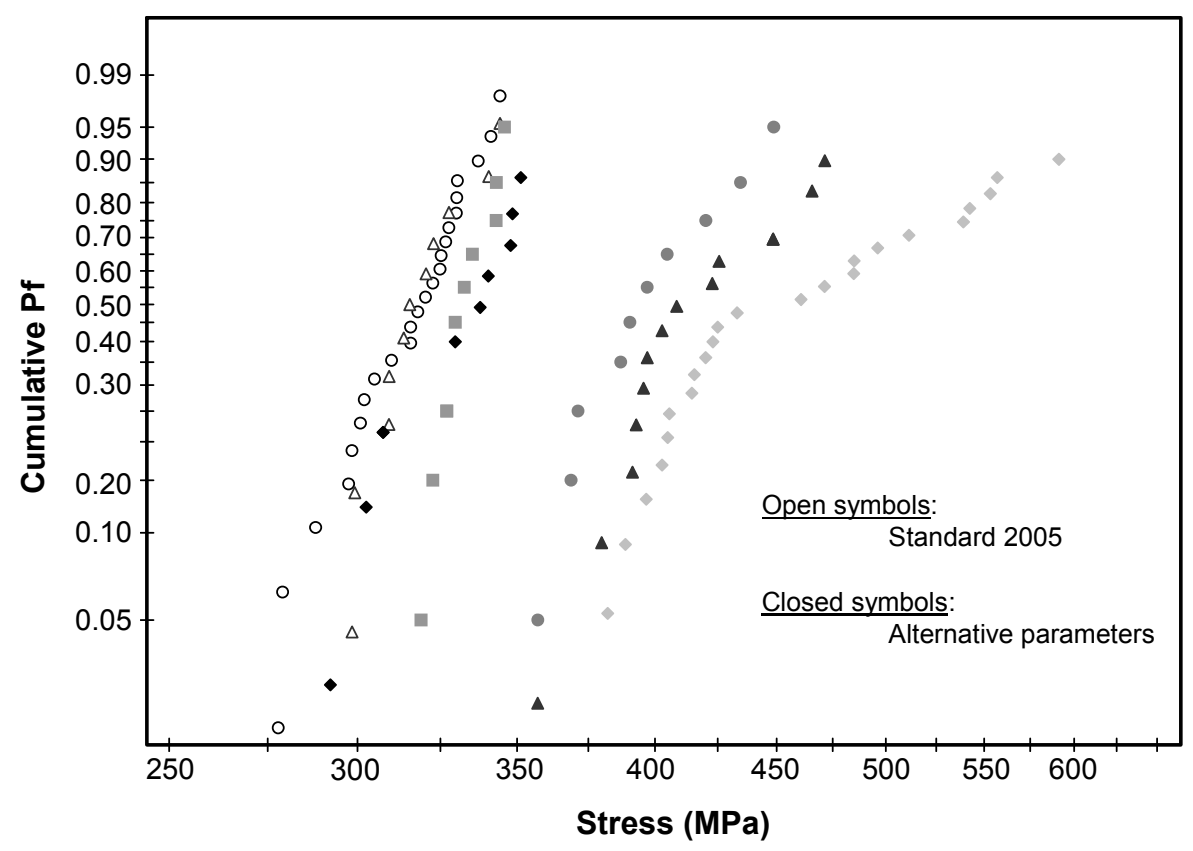

Figure 2. Statistical distribution (Weibull plot) of mechanical strength data for various anode supports

The pre-pilot production relies on a spraying process for cathode deposition (5). Due to the ease of up-scalability and with the aim to further improve the reproducibility of the cell production (2), screen printing is being investigated as an alternative route. Cathode performances measured on screen printed cathodes (symmetrical cells based on $150 \mu \mathrm{m}$ zirconia tapes) are compared to sprayed ones in Figure 3 (6). Evidently, the screen printed cathodes match the sprayed cathodes, and this process is thus considered for use on future large area cells.

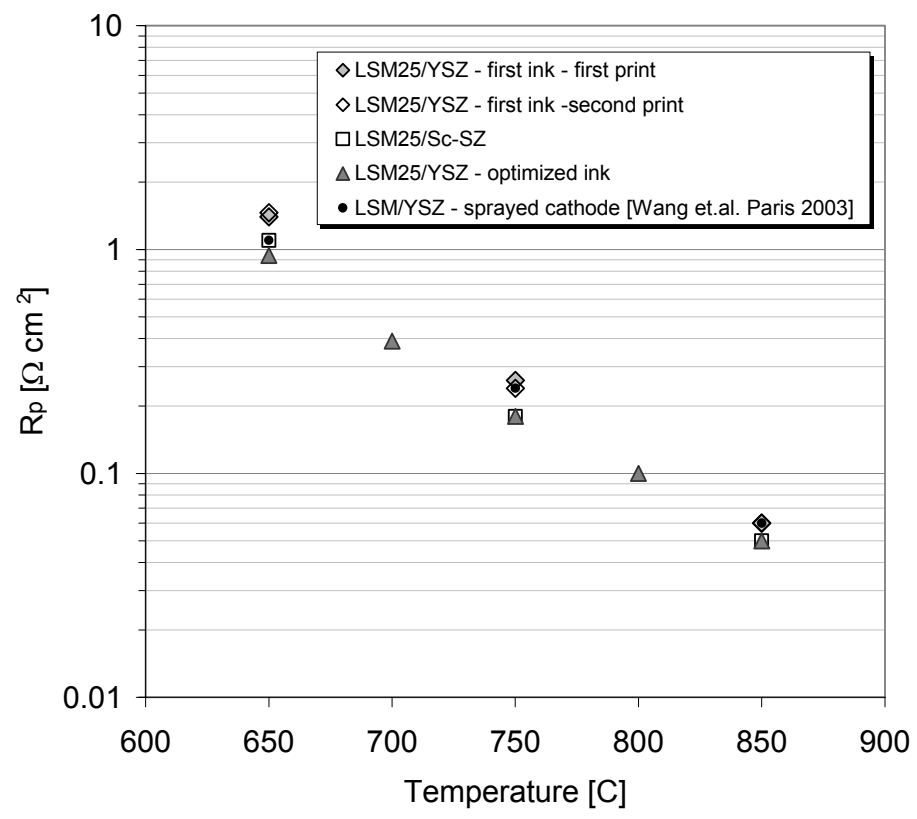

Figure 3. $R_{\mathrm{p}}$ values for symmetric cells with YSZ/LSM cathodes on YSZ electrolyte. A cathode with $\mathrm{ScSZ}$ is also shown for comparison. Sprayed cathode from Wang et al (7) . 
A completely new cell type based on a FeCr alloy support for operation below $700{ }^{\circ} \mathrm{C}$ is also being developed. For this cell type it is not only the support material that is new; cathode, electrolyte and anode are also based on a new materials choice. So far $3 \mathrm{G}$ cells up to $12 \times 12 \mathrm{~cm}^{2}$ have been manufactured successfully. However, the electrical performance still lacks behind that of the anode supported cell.

\section{G Cell durability}

The $2 \mathrm{G}$ cells manufactured in the production line are generally very durable at high temperature $\left(850^{\circ} \mathrm{C}\right)$ even at very high current loads $(8)$. The degradation rate increases with increasing polarization. At a current density of $0.25 \mathrm{~A} / \mathrm{cm}^{2}$ (operating voltage $\sim 850$ $\mathrm{mV}$ ) the voltage degradation rate is less than $0.25 \% / 1000 \mathrm{~h}$ and at $1 \mathrm{~A} / \mathrm{cm}^{2}$ (corresponding to an operating voltage $\sim 750 \mathrm{mV}$ ) the degradation is below $0.6 \% / 1000 \mathrm{~h}$ (See also Figure 5, upper curve). Operating the cells at $750{ }^{\circ} \mathrm{C}$ also provide excellent durability when operating at normal polarization levels. However, under severe operating conditions at $750{ }^{\circ} \mathrm{C}$, i.e. exposed to a strong polarization, a marked degradation is observed. This degradation has been identified to mainly originate from the cathode/electrolyte interface $(8,9)$. Efforts are being devoted to develop cells that are also capable of long term operation under these conditions, to enhance the window of operation of the technology. Recently, progress has been achieved in this field. Figure 4 shows the cell voltage of the standard $2 \mathrm{G}$ cells as well as a cell with a modified cathode as a function of operating time under high polarization at $750{ }^{\circ} \mathrm{C}$. The introduced modification of the cathode effectively results in stable operation, even under these severe conditions, after an initial degradation occurring over the first $500 \mathrm{~h}$.

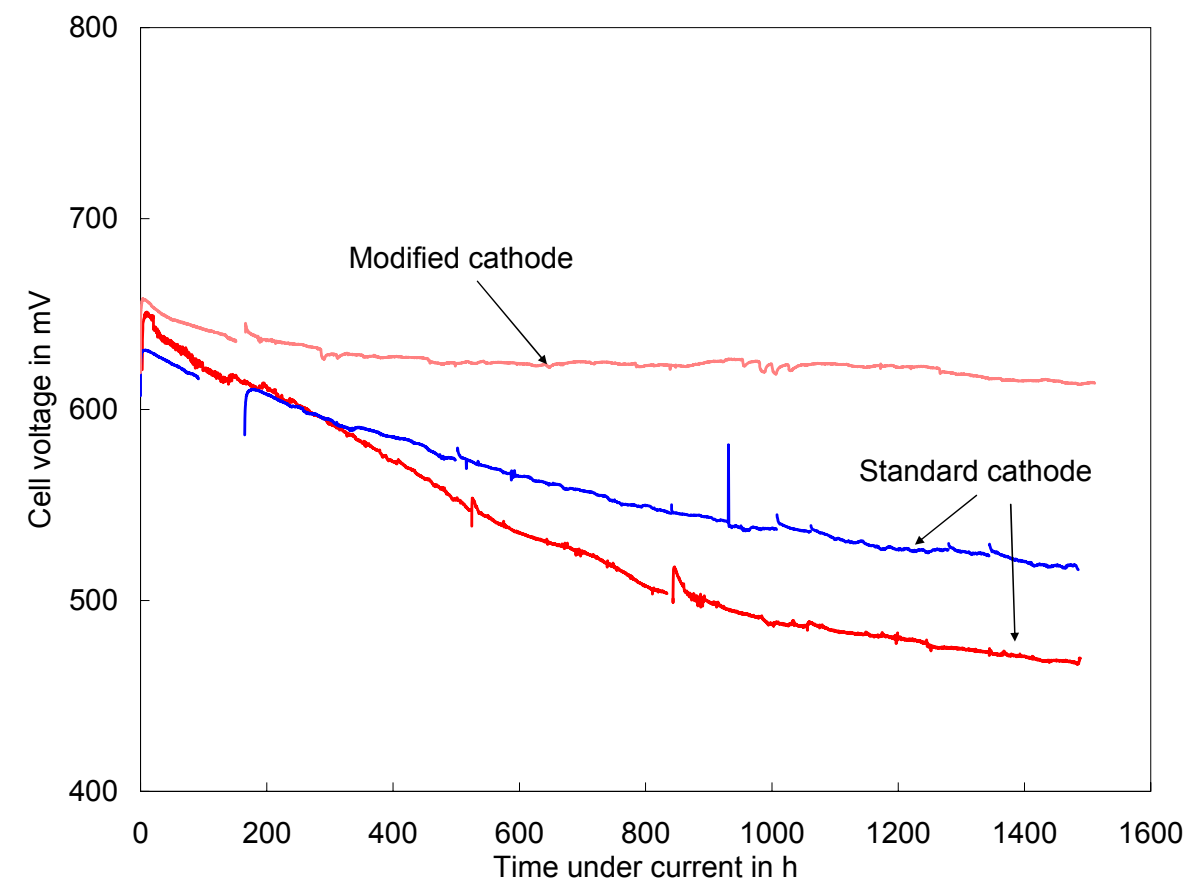

Figure 4. Stability of modified LSM cathodes in accelerated aging test ("low temperature, high polarization"). The temperature was $750{ }^{\circ} \mathrm{C}$, the current density was $0.75 \mathrm{~A} / \mathrm{cm}^{2}$, and the cells operated on a syn-gas mixture with a fuel utilization of $\sim 80 \%$. 


\section{Effect of Sulphur on Cell Durability}

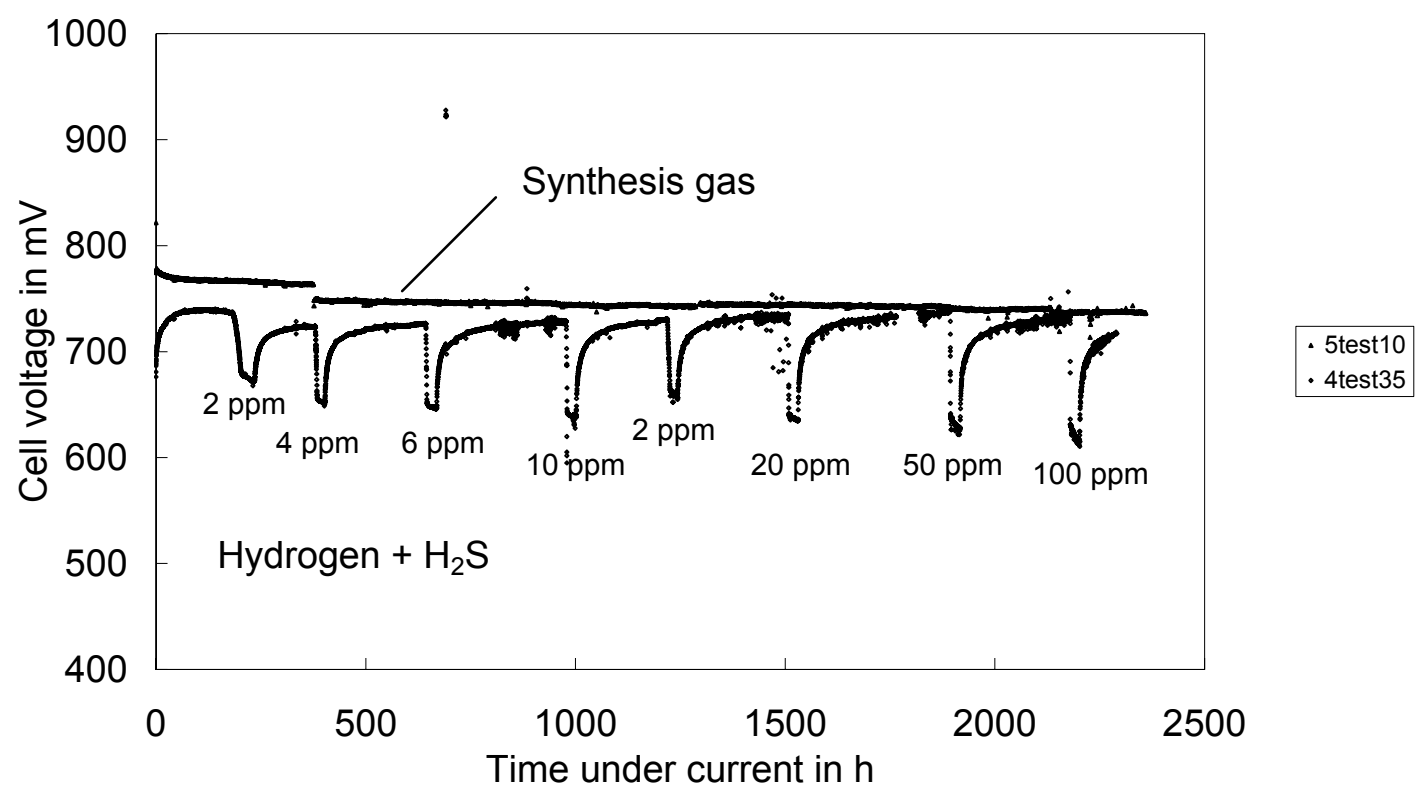

Figure 5. Cell durability at $850{ }^{\circ} \mathrm{C}, 1 \mathrm{~A} / \mathrm{cm}^{2}$. The upper curve is for a cell operated in syngas with a fuel utilization of $75 \%$. The lower curve is for a cell operating at the same temperature and current load but in hydrogen with various amounts of $\mathrm{H}_{2} \mathrm{~S}$ added periodically.

When using fuel derived from biomass in SOFCs, one must be aware of trace amounts of different impurities which may act as poison for the electrochemical processes. One such impurity is $\mathrm{H}_{2} \mathrm{~S}$, which is also used as odorant in natural gas lines. The sulphur tolerance of the anodes is currently studied. The effect of small amounts of $\mathrm{H}_{2} \mathrm{~S}$ in hydrogen on the performance and durability of a "standard" $2 \mathrm{G}$ cell was studied at $850{ }^{\circ} \mathrm{C}$ and $1 \mathrm{~A} / \mathrm{cm}^{2}$ (see Figure 5). The cell voltage decreased and the degradation rate increased during the periods under $\mathrm{H}_{2} \mathrm{~S}$. However, these changes were completely reversible up to the studied concentration of $100 \mathrm{ppm}_{2} \mathrm{~S}$ (10). Turning off the sulphur addition results in a recovery of the cell performance over a period of $\sim 250 \mathrm{~h}$, and the overall degradation tracked over $2000 \mathrm{~h}$ is less than for the reference case. Thus, it is concluded that the sulphur reduces the reaction rate by passivation of reaction sites by adsorption.

\section{Stack Development and Production}

Due to the very compact stack design including thin-plate metallic interconnects, a stack volume power density of $2.4 \mathrm{~kW}$ per litre stack volume has been obtained in crossflow configuration with hydrogen fuel at $0.35 \mathrm{~W} / \mathrm{cm}^{2}$. Standard stacks have been tested successfully for more than $13000 \mathrm{~h}$. Post-mortem analyses have revealed the dominating degradation mechanisms. Recently, the degradation rate has been reduced to below $0.5 \%$ per $1000 \mathrm{~h}$ by introduction of improved stack component materials, including improved metallic interconnects. Several 50 - or 75 -cell stacks in the $1+\mathrm{kW}$ power range have been tested successfully on methane rich reformate gas at a fuel utilisation up to $92 \%$. Figure 6 shows the I/V performance of a 75-cell $\left(12 \times 12 \mathrm{~cm}^{2}\right)$ stack with counter flow 
configuration. Stack and system modelling including cost optimisation analysis is used to develop $5-25 \mathrm{~kW}$ stack modules for operation in the temperature range $700-850^{\circ} \mathrm{C}$.

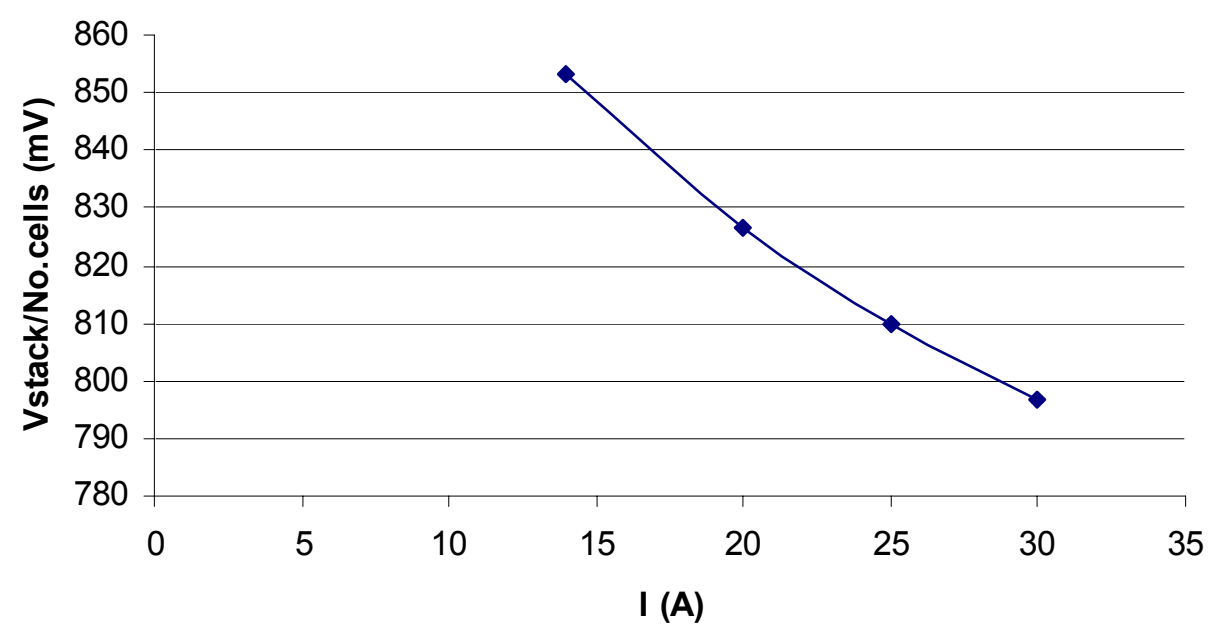

Figure 6. I/V performance of a 75-cell $\left(12 \times 12 \mathrm{~cm}^{2}\right)$ counter flow at $800^{\circ} \mathrm{C}, 65 \%$ fuel utilisation with pre-reformed natural gas.

A special effort is focused on manufacturing and testing of larger anode-supported cells and stacks with a foot print of $18 \times 18 \mathrm{~cm}^{2}$. Figure 7 shows the performance of a seven-cell stack with $18 \times 18 \mathrm{~cm}^{2}$ cells operated at $800^{\circ} \mathrm{C}$. It is seen that at a steady state current of $45 \mathrm{~A}$, the degradation rate is below the detection limit after $500 \mathrm{~h}$ for both $\mathrm{H}_{2}$ and $\mathrm{CH}_{4}$ fuels.

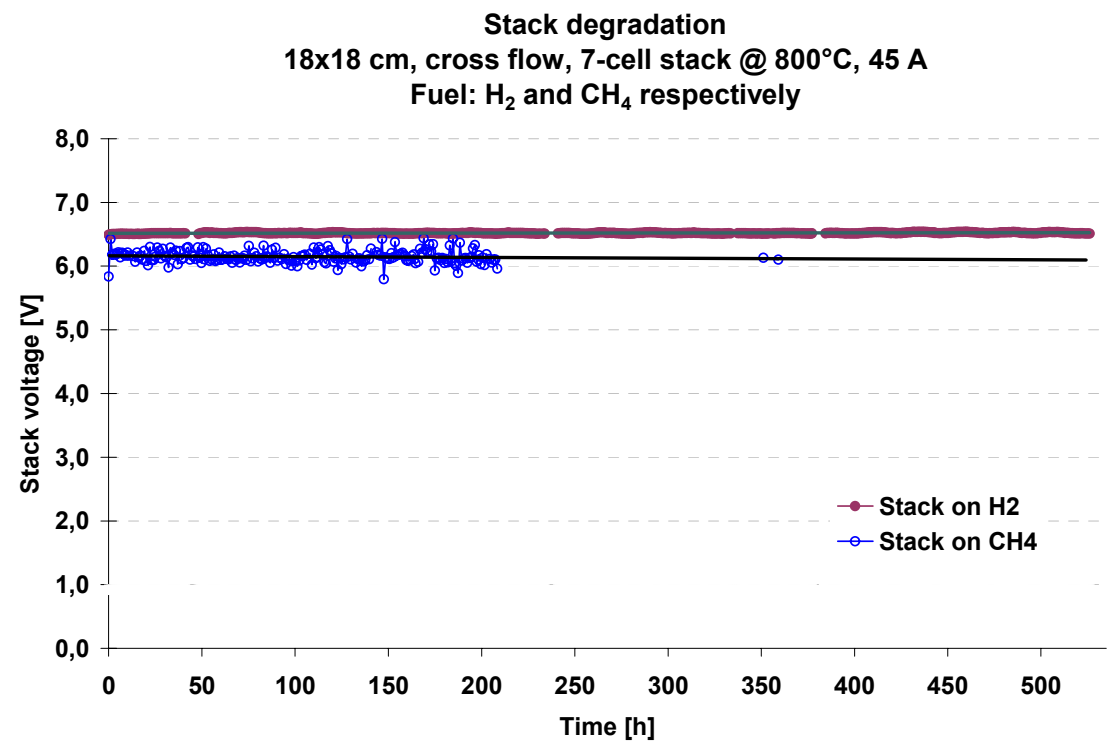

Figure 7. Degradation curves for $18 \times 18 \mathrm{~cm}^{2}$ cell stack, $\mathrm{H}_{2} / \mathrm{N}_{2}$ fuel (upper curve) and $\mathrm{CH}_{4} / \mathrm{H}_{2} \mathrm{O}$ (lower curve), steady state current $45 \mathrm{~A}$. 


\section{Next Generation Stacks and Hot Box Modules}

The next generation stacks include an improved integrated metallic interconnect design aiming at further weight saving, cost reduction and reduction of internal stack pressure drop. An integrated hot box $1,8 \mathrm{~kW}_{\mathrm{el}}$ module, including new stack design, stack clamping system and thermal insulation has been developed and is currently tested by UTRC under a US Air Force demonstration project.

Further stack generation development is based on cells with metallic support as described above. The stacks are tailored to minimize parameters such as weight, pressure drop, start-up time and cost and to maximize robustness, durability, performance and redox stability.

\section{Fuel Processing and System Development}

A range of fuels have previously been studied including natural gas, LPG, methanol, DME, diesel and ammonia. The studies predict system electrical efficiencies from 50$56 \%$ (AC out/LHV fuel in), depending on the fuel used and the size of the system. The range of fuels have now been extended to include ethanol and coal syn-gas (11) by development of a new coke resistant ethanol reforming/methanation catalyst and leveraging the catalyst know-how of HTAS involved in high temperature methanation of coal gas respectively.

TOFC has collaborated with Wärtsilä since 2002 on the development of SOFC systems in the $200+\mathrm{kW}$ class, primarily for power generation and marine application. Since late 2004 Wärtsilä has operated the SOFC test system with planar SOFC stacks developed and manufactured by TOFC. During spring 2006 four stacks were installed, each having a nominal power of $1 \mathrm{~kW}$. The system has been in continuous operation providing an average power of $3.6 \mathrm{~kW}$ at $55-60 \%$ fuel utilisation (FU), this being a valid reference point for further system development and up-scaling. The in total $4000 \mathrm{~h}$ of operation indicates very good reliability of the used stack and system technologies. In Figure 8, the power curve combined with average FU for the four stacks is presented (12).

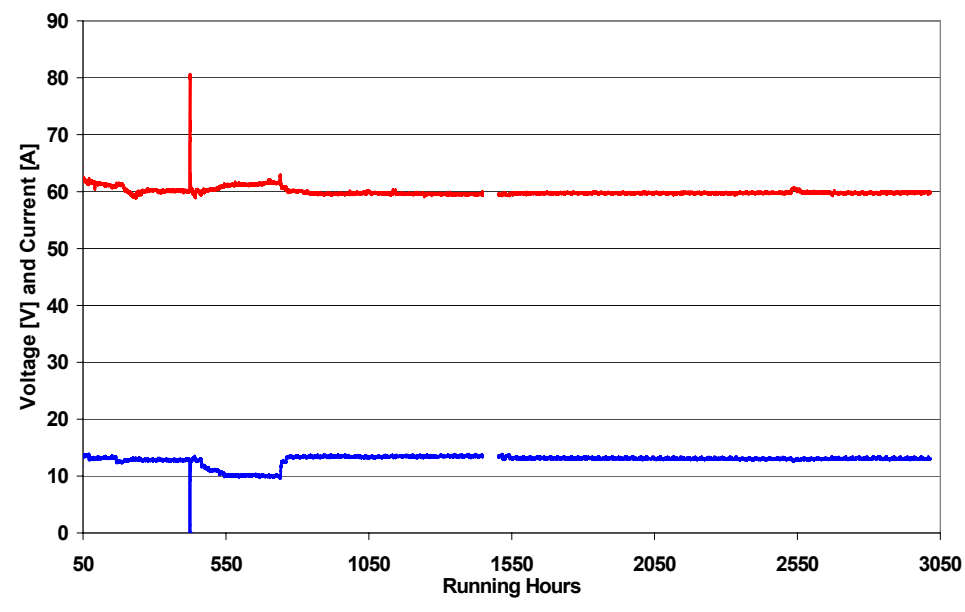

Figure 8. Average stack voltage (upper curve) and current (lower curve) of 75-cell stacks in a four stack system. 
In collaboration with Wärtsilä, a detailed design for a 24-stack prototype based on natural gas has been finalised and 24 stacks of the 75 cell $\left(12 \times 12 \mathrm{~cm}^{2}\right)$ type to Wärtsilä by TOFC. Another 24-stack prototype, now based on methanol as the fuel, is also under construction by Wärtsilä. The methanol is methanated upstream the anode, using a newly developed, proprietary Haldor Topsoe catalyst.

Two Danish projects in the PSO program supported by the Danish Utilities have been initiated. One is aiming at demonstrating a $1 \mathrm{~kW}_{\mathrm{e}}$ micro-CHP unit and the other is a 10 $\mathrm{kW}_{\mathrm{e}}$ stack demonstration facility including fuel processing and power conversion located at a power station in Copenhagen, Denmark.

\section{Acknowledgements}

Energinet.dk, PSO F\&U projects, Danish National Advanced Technology Foundation: "Robust, environmentally friendly and cost efficient fuel cell systems for future power production".

\section{References}

1. S. Ramousse, M. Menon, K. Brodersen, U. Rahbek and P.H. Larsen. In these proceedings.

2. A. Hagen, M. Menon, R. Barfod, P.V. Hendriksen, S. Ramousse and P.H. Larsen, Fuel Cells 146-150 (2006).

3. M. Pihlatie, A. Kaiser, P.H. Larsen and M. Mogensen. In these proceedings.

4. D. Beeaff, S. Ramousse and P.V. Hendriksen, in Ceramic Engineering and Science Proceedings, 27, 4, Cocoa Beach, FL (2006).

5. N. Christiansen, J.B. Hansen, H. Holm Larsen, S. Linderoth, P.V. Hendriksen, P.H. Larsen and M. Mogensen, in 7th European SOFC Forum, J.A. Kilner, Chair, B034, Lucerne, Switzerland 2006.

6. M. Wandel et al. To be published elsewhere.

7. W.G. Wang, R. Barfod, P.H. Larsen, K. Kammer Hansen, J. Bentzen, P.V. Hendriksen and M. Mogensen, In Proceedings 8. International Symposium on Solid Oxide Fuel Cells (SOFC VIII); S.C. Singhal, and M. Dokiya, Editors, PV2003-07, p. 400, The Electrochemical Society Proceedings Series, Pennington, NJ (2003).

8. A . Hagen, R. Barfod, P.V. Hendriksen, Y.-L. Liu and S. Ramousse, J. Electrochem. Soc. 153, A1165-A1171 (2006).

9. A. Hagen, Y.-L. Liu, R. Barfod, and P.V. Hendriksen, in these proceedings.

10. J. Rasmussen et al. To be published elsewhere.

11. J. Hansen, T. Rostrup-Nielsen and J. Pålsson, in these proceedings.

12. E. Fontell, T. Kivisaari, K. Åström, J.B. Hansen and N. Christiansen, Fuel Cell Seminar, Honolulu, 2006. 